\title{
Uji Aktivitas Ekstrak Buah Merah (Pandanus conoideus) sebagai Hepatoprotektor pada Hati Mencit Galur Swiss yang Diinduksi dengan $\mathrm{CCl}_{4}$
}

\author{
Arina Swastika Maulita \\ Program Studi Farmasi Fakultas Ilmu Kesehatan Universitas Muhammadiyah Malang \\ email: arinaswastika@yahoo.com
}

\begin{abstract}
Liver is an the important organ, it plays an essential role in maintaining the biological equilibrium of vertebrates. Reactive oxygen species $(R O S)$ play an important role in pathological changes in the liver. The research has been carried out to know the potential use of buah merah (Pandanus conoideus) extract as hepatoprotrctive agent against $\mathrm{CCl}_{4}$ poisoning in mice. In this study, the hepatoprotective activity was determined by the reduction of SGPT (serum glutamic pyruvate transaminase) and SGOT (serum glutamic oxaloacetic transaminase) level. Application of buah merah extract significantly $(p<0,05)$ reduced SGPT and SGOT level. Microscopically, several changes were found, such as severe hydrofic degeneration and necrosis at liver cell that treated by $\mathrm{CCl}_{4}$. Base on histological examination of application of buah merah extract, could inhibit damage and reduced the degeneration and necrosis of liver cell.
\end{abstract}

Key word: Buah merah, SGPT, SGOT, hepatoprotective.

\section{PENDAHULUAN}

Hati (liver) merupakan organ yang memegang peranan penting dalam pemeliharaan keseimbangan biologi tubuh dari vertebrata. Hati mempunyai fungsi dalam mengatur metabolisme xenobiotik, memetabolisme lipid, karbohidrat, dan protein serta mengatur koagulasi darah dan imunomodulasi (Mishra dan Bafna, 2004).

Kerusakan hati dapat disebabkan oleh infeksi maupun aktifitas senyawa kimia yang masuk kedalam tubuh dengan berbagai macam mekanisme aksi. Kerusakan hati yang diawali dengan meningkatnya steatosis dan akhirnya fibrosis pada hati yang dapat menyebabkan kematian. Meskipun patogenesis fibrosis belum begitu jelas, tapi tidak menuntut kemungkinan spesies oksigen reaktif (SOR) berperan dalam perubahan patologis dalam hati, terutama pada kasus penyakit hati yang disebabkan oleh alkohol dan racun (Poli dan Parola, 1997). Membran sel berperan penting dalam melawan efek SOR sehingga proses peroksidasi pada asam lemak tidak jenuh pada membran menyebabkan penurunan integritas dan fungsi membran yang berimplikasi pada perubahan patologis yang serius (Halliwell,
1987). Beberapa mekanisme proteksi alami tubuh terlibat dalam pengurangan kerusakan hati yang disebabkan oleh peroksidasi (Sies, 1993). Namun demikian, karena proteksi yang terganggu atau ketika peningkatan SOR, mekanisme proteksi tambahan melalui konsumsi antioksidan sangat diperlukan. Banyak bahan alam yang menunjukkan sifat antioksidan disarankan dalam pencegahan dan pengobatan penyakit hati yang disebabkan oleh radikal bebas (Lieber, 1997).

Pada beberapa tahun terakhir ini, buah merah (Pandanus conoideus) mulai banyak digunakan untuk pengobatan alternatif terhadap beberapa penyakit degeneratif dan kanker. Buah merah yang paling banyak dipakai adalah species Pandananus conoideus dengan buah merah marum, agak pendek dan biji agak besar dibandingkan dengan spesies yang lainnya (Budi dan Paimin, 2005).

Dalam penelitian diketahui buah merah mengandung karoten dan tokoferol yang merupakan senyawa antioksidan tinggi (Sathyabudi, 2005). Kedua senyawa ini dapat digunakan untuk pencegahan dan pengobatan penyakit hati yang disebabkan 
oleh adanya species oksigen reaktif (SOR) dalam perubahan patologi hati. Menurut Bass (1999) senyawa-senyawa yang mengandung gugus hidroksi atau polihidroksi pada buahbuahan, sayur dan beberapa tanaman lain berperan penting dalam aksi hepatoproteksi seperti yang dimiliki oleh karoten dan tokoferol.

\section{METODOLOGI PENELITIAN Alat dan Bahan}

Bahan yang digunakan dalam penelitian ini adalah ekstrak buah merah Papua Wonder Red (Sari Buah Merah) produksi Saka Farma Laboratories, Semarang; Obat standar hepatoprotektor (Hepasil); Karbon tetraklorida $\left(\mathrm{CCl}_{4}\right)$; Formalin $10 \%$, zat warna Hematoksilin Eosin; xylol, alkohol $70 \%$, alkohol $80 \%$, alkohol $90 \%$, alkohol 96\%, alkohol absolut, SGPTSGOT complete reagent test; CMC; metanol; aquadest semua dalam standar kimia.

Alat yang digunakan adalah timbangan hewan, sentrifuse; alat tes SGOT dan SGPT (Cobas Integra); tissue processor, mikroskop, mikrotom, oven, vial, spuit injeksi, sonde, alat bedah, tabung mikrosentrifugasi, water bath, hot plate, obyek glass, cover glass dan alat-alat gelas yang sesuai.Hewan uji yang digunakan berupa mencit jantan galur Swiss (20-40g).

\section{Tempat Penelitian}

Penelitian dilakukan di

Laboratorium Biomedik Farmasi Program Studi Farmasi Universitas Jember, Laboratorium Patologi Veteriner Kedokteran Hewan Universitas Airlangga dan Laboratorium Klinik Pramita Jember.

\section{Pembuatan Suspensi Hepasil (Obat standar)}

Hepasil kapsul sebagai obat standar digunakan sebagai pembanding dibuat dengan cara mensuspensikan dalam CMC 1 $\%$ dengan dosis 4 kapsul hepasil dalam 100 $\mathrm{mL}$ aquadest.

\section{Pelaksanaan Penelitian}

Mencit galur Swiss sebanyak 30 ekor (20-40g) dibagi secara acak dalam 3 kelompok. Kelompok pertama sebagai kontrol negatif, kelompok kedua sebagai kelompok perlakuan, kelompok ketiga sebagai kelompok pembanding. Kelompok hewan uji dipuasakan selama semalam sebelum diberikan perlakuan. Kemudian kelompok pertama diberi aquadest $0,5 \mathrm{ml}$, kelompok kedua diberi larutan buah merah $0,117 \mathrm{ml} / 20 \mathrm{~g}$ secara (p.o) dan kelompok ketiga diberi obat standar hepatoprotektor (hepasil) 0,26ml/20g (p.o) selama 7 hari berturut-turut. Setelah 7 hari pemberian, hewan uji dipuasakan selama 16 jam dan selama tiga hari semua kelompok hewan uji diberi $\mathrm{CCl}_{4} 5,0 \mathrm{ml} / \mathrm{kg} \mathrm{BB}$ per oral (Thakore and Mehendale, 1991).

\section{Pengambilan Darah Hewan uji}

Pengambilan darah pada mencit dilakukan setelah hari ketiga pemberian $\mathrm{CCl}_{4}$. Darah mencit diambil melalui vena cavilla ocularis yang ada di mata dengan menggunakan kapiler. Darah kemudian ditampung dalam tabung mikrosentrifugasi untuk diambil serumnya yang kemudian dilakukan pengujian terhadap aktivitas SGOT dan SGPT.

\section{Pengambilan Organ Hati Hewan Uji}

Pengambilan organ hati dilakukan pada hewan uji yang berbeda namun diberi perlakuan yang sama dengan hewan uji yang digunakan untuk pengambilan darah untuk pengujian aktivitas SGOT dan SGPT.

Hewan uji yang telah diberi perlakuan kemudian dibedah dan diambil organ hatinya. Organ hati yang didapat difiksasi dengan larutan formalin $10 \%$ untuk dibuat preparat histopatologik. Kondisi organ dalam larutan formalin harus terendam seluruhnya dan waktu perendaman tidak kurang dari 24 jam.

\section{Pembuatan dan Pemeriksaan Preparat Histopatologi}

Pembuatan Preparat Histopatologi

Prosedur pembuatan preparat histopatologi menurut Martoprawiro (1996) dalam Romzah (2005) adalah dengan cara: fiksasi, dehidrasi dan clearing, embedding, bloking, pemotongan, pengecataan/ pewarnaan dan mounting.

Fiksasi dan pencucian dilakukan setelah hewan percobaan mati setelah dibedah, kemudian organ hati diambil dan dimasukkan formalin 10 persen sekurangkurangnya 24 jam. Selanjutnya dilakukan pencucian dengan menggunakan air kran. Kemudian dilakukan proses dehidrasi dan clearing yaitu hepar yang telah dicuci dengan air kran selama 30 menit lalu dimasukkan 
ke dalam alkohol dengan konsentrasi $70 \%$, $80 \%$, 95\%, 96\%, alkohol absolut I, II, III, xylol I, II dan III masing-masing selama 30 menit

Embedding adalah proses melekatkan organ dengan parafin. Organ dimasukkan ke dalam parafin I yang masih cair, kemudian dimasukkan ke dalam oven suhu $55^{\circ}-56^{\circ} \mathrm{C}$ selama 30 menit. Selanjutnya organ dimasukkan ke dalam parafin II yang masih cair dan dipindahkan ke dalam oven pada suhu $60{ }^{\circ} \mathrm{C}$ selama 30 menit. Hasil dari embedding kemudian dibuat balok parafin (blocking) dengan terlebih dahulu menyiapkan beberapa cetakan besi yang diolesi dengan glyserin agar parafin tidak melekat pada besi. Cetakan diisi parafin cair organ kemudian dimasukkan ke dalam cetakkan, ditunggu sampai parafin membeku. Setelah parafin membeku dilakukan pemotongan blok parafin dengan menggunakan mikrotum dengan ketebalan 4 - $7 \mathrm{~mm}$. Hasil potongan dimasukkan ke dalam water bath dengan suhu $42^{\circ}-45^{\circ} \mathrm{C}$ sampai jaringan mengembang kemudian dikeringkan dalam hot plate.

Pengecataan atau pewarnaan merupakan proses mewarnai preparat agar memudahkan melihat perubahan pada jaringan. Pewarnaan organ hati menggunakan Hematoxylin Eosin (HE). Pewarnaan dilakukan setelah jaringan yang kering dimasukkan ke dalam xylol I selama 5 menit, xylol II 4 menit, xylol III selama 3 menit. Jaringan selanjutnya dimasukkan ke dalam alkohol absolut I (3 menit), alkohol absolut II (2 menit), dan alkohol absolut III (3 menit), alkohol 95\% (2 menit), alkohol 90\% (2 menit), alkohol 80\% (1 menit), alkohol $70 \%$ (1 menit) dan dicuci dengan air kran mengalir selama 5 menit. Proses selanjutnya jaringan dimasukkan ke dalam zat warna hematoxylin Eosin (HE) selama 4-10 menit kemudian dicuci dengan air kran mengalir selama 10 menit, jaringan dimasukkan ke dalam eosin selama 3-8 menit kemudian dimasukkan berturut-turut ke dalam alkohol 70\% (1 menit), $80 \%$ (2 menit), 90\% (3 menit) dan alkohol absolut I (3 menit), alkohol absolut II (3 menit) dan alkohol absolut III (3 menit). Selanjutnya jaringan dimasuk kedalam xylol I (3 menit), xylol II (4 menit) dan xylol III (5 menit). Proses terakhir adalah mounting yaitu penutupan gelas obyek dengan gelas penutup yang sebelumnya telah ditetesi menggunakan entellan atau kanada balsem.

Pemeriksaan Preparat Histopatologi

Selanjutnya pemeriksaan dilakukan di bawah mikroskop cahaya dengan perbesaran 10 x 40 (Rusmiati dan Lestari, 2004; Suarsana dan Budiasa, 2005). Penentuan perubahan histopatologi dilakukan berdasarkan batasan yang dikemukakan oleh Romzah (2005) sebagai berikut :

Degenerasi sel : terdapat perubahan pada sitoplasma sel berupa pembengkakan, akulasi air atau lemak.

Nekrosis sel : terdapat perubahan pada inti sel berupa penggumpalan, reksis atau lisis

Pemeriksaan preparat histopatologi dianalisis secara deskriptif selain itu untuk membandingkan keseluruhan gambaran preparat dilakukan pengamatan hepatosit pada tiap lapang pandang. Pengamatan histopatologi hati diberi skor untuk setiap ulangan pada setiap kelompok perlakuan Perubahan gambaran histopatologi hati mencit normal bertanda negatif (-) diberi skor 0 dan bila bertanda positif (+) diberi skor 13.

Pemberian skor untuk masingmasing tingkat perubahan gambar histopatologi hati mencit dapat dilihat dalam Tabel 1 Skor perubahan gambaran histopatologi hati mencit tersebut, kemudian di jum thistonatolog thati perdasarkan adanyan rata-rata yari tiap kelompok (Dewi, 2002).

\begin{tabular}{lccc}
\hline Bentuk Perubahan & Nilai & Degenerasi Sel & Nekrosis Sel \\
\hline Negatif $(-)$ & 0 & Tidak terjadi degenerasi & Tidak terjadi nekrosis \\
Positif $(+)$ & 1 & Degenerasi sempit & Nekrosis sempit \\
& 2 & Degenerasi sedang & Nekrosis sedang \\
& 3 & Degenerasi luas & Nekrosis luas \\
\hline
\end{tabular}

Keterangan :

Sempit : Apabila dalam 1 lapang pandang $=25 \%$ sel mengalami nekrosis

Sedang : Apabila dalam 1 lapang pandang $\pm 50 \%$ sel mengalami nekrosis

Luas : Apabila dalam 1 lapang pandang $=75 \%$ sel mengalami nekrosis

Dari rata-rata skor yang di dapatkan dari masing-masing perubahan gambaran histopatologi hati, baik berdasarkan adanya degenerasi ataupun nekrosis kemudian dihitung persentasenya yang dinyatakan 
sebagai persentase kerusakan hati.

\section{Penentuan Aktivitas SGPT dan SGOT Serum Darah}

Prinsip penetapan SGOT dan SGPT menggunakan metode kinetik yang sesuai dengan International Federation of Clinical Chemistry (IFCC) tanpa piroksidal -5-fosfat mengguanakan alat COBAS INTEGRA.

Penentuan aktivitas SGPT dan SGOT serum darah dilakukan pada hewan uji yang telah diberi $\mathrm{CCl}_{4}$ selama tiga hari. Pengambilan darah melalui vena cavilla ocularis mata menggunakan pipa kapiler. Darah disentrifugasi untuk diambil serumnya sebanyak $0,1 \mathrm{~mL}$ dan dicampur dengan reagen SGPT atau SGOT sebanyak $1 \mathrm{~mL}$ yang lebih dahulu dihangatkan pada suhu $37^{\circ} \mathrm{C}$. Campuran serum dan reagen dimasukkan ke dalam alat COBAS INTEGRA dan diukur pada panjang gelombang $340 \mathrm{~nm}$. Pengukuran dilakukan sebanyak empat kali dengan interval $30 \operatorname{detik}\left(\mathrm{A}_{0} \mathrm{~A}_{1}\right.$, $\mathrm{A}_{2}$ dan $\mathrm{A}_{3}$ ). Hasil dari aktivitas SGOT dan SGPT dinyatakan dalam satuan unit/liter (U/ L) yang merupakan banyaknya enzim dalam satu liter serum yang dapat menghasilkan $\mathrm{NAD}^{+}$pada satuan waktu yang sama. (The Committee on Enzymes of the Scandinavian Society for Clinical Chemistry and Clinical Physiology, 1974). Analisa data aktivitas SGPT dan SGOT kemudian dilakukan uji Anava dan apabila terjadi perbedaan secara signifikan maka akan dilanjutkan dengan LSD (Least Significant Difference).

\section{HASIL PENELITIAN}

\section{Pemeriksaan Aktivitas SGPT dan SGOT}

Serum darah pada masing-masing kelompok uji diperiksa aktivitas SGOT dan SGPT menggunakan metode kinetik. Hasil anava yang didapatkan menunjukkan perbedaan antara kelompok 1 sebagai kontrol negatif terhadap kelompok 2 sebagai kelompok perlakuan dan kelompok 3 yang merupakan kelompok pembanding. Perbedaan tersebut dapat dilihat pada Tabel 2.
Aktivitas SGPT dan SGOT ditunjukkan pada histogram rata-rata aktivitas SGPT dan SGOT pada masingmasing kelompok pada Gambar 1.

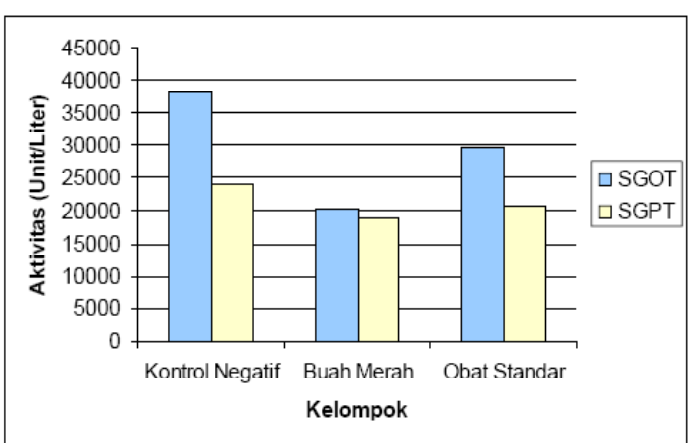

Gambar 1. Perbandingan Rata-rata Aktivitas SGPT dan SGOT

Aktivitas serum SGOT dan SGPT kemudian dianalisis dengan uji anava kemudian dilanjutkan dengan LSD. Berdasarkan analisa anava satu arah didapatkan nilai $\mathrm{F}$ hitung aktivitas SGPT (669.090) dan SGOT (42.660) yang lebih kecil dibandingkan $\mathrm{F}$ tabel $(3,89)$ sehingga dapat disimpulkan bahwa aktivitas SGPT dan SGOT berbeda secara signifikan.

Berdasarkan hasil analisa menggunakan LSD $(\alpha=0,05)$ diketahui selisih rata-rata dari masing-masing kelompok berbeda signifikan $(p<0,05)$.

\section{Pemeriksaan Histopatologi}

Pemeriksaan histopatologi hati bertujuan untuk mengetahui gambaran hepatosit terhadap masing-masing kelompok secara mikroskopis setelah diinduksi dengan hepatotoksik $\left(\mathrm{CCl}_{4}\right)$. Pemeriksaan histopatologi hati dilihat berdasarkan pengamatan lapang pandang. Pengamatan menggunakan 10 lapang pandang secara acak terhadap dua preparat. Adapun penilaian berdasarkan perbandingan skor perubahan gambaran histopatologi hati yang dikarenakan adanya degenerasi sel dan nekrosis.

Gambar perbandingan hepatosit normal dan hepatosit yang mengalami

Tabel 2 Hasil Pemeriksaan Aktivitas SGOT dan SGPT

\begin{tabular}{cccc}
\hline & \multicolumn{3}{c}{ Kelompok } \\
\hline & $\begin{array}{c}\text { Kontrol Negatif } \\
\text { Rata-rata } \pm \text { SD }\end{array}$ & $\begin{array}{c}\text { Buah Merah } \\
\text { Rata-rata } \pm \text { SD }\end{array}$ & $\begin{array}{c}\text { Obat Standar } \\
\text { Rata-rata } \pm \text { SD }\end{array}$ \\
\hline SGOT (Unit/Liter) & $38224,4 \pm 2,92$ & $20112,4 \pm 2,68$ & $29732,4 \pm 1,85$ \\
\hline SGPT (Unit/Liter) & $24128 \pm 5,22$ & $18923 \pm 2,77$ & $20640,8 \pm 3,78$ \\
\hline
\end{tabular}

Data disajikan berdasarkan pengujian pada suhu optimum $37^{\circ} \mathrm{C}$ 

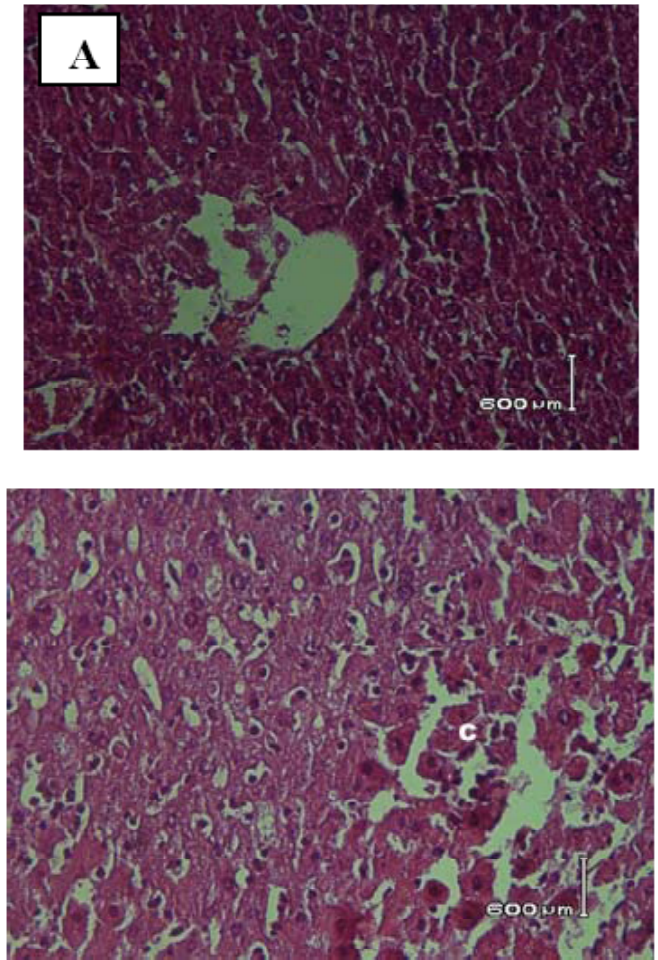
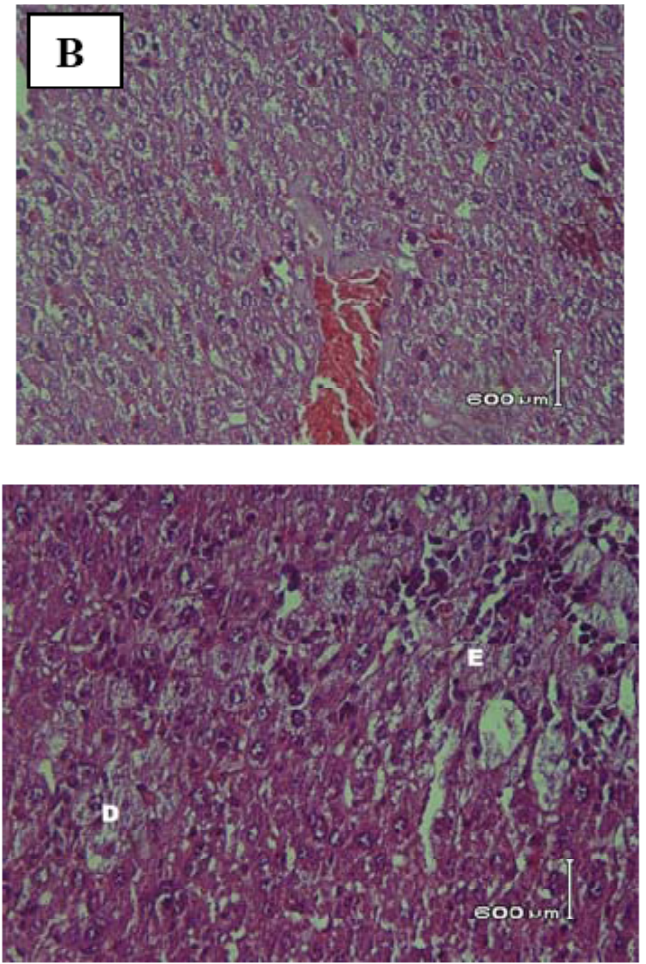

Gambar 2 Gambaran Mikroskopis Hepatosit Mencit Setelah Perlakuan

(A) gambaran mikroskopis hepatosit normal; (B) gambaran mikroskopis kerusakan hati menyeluruh; (C) hepatosit normal; (D) hepatosit yang mengalami degenerasi sel; dan (E) hepatosit yang mengalami nekrosis

Tabel 3 Skor Perubahan Gambaran

Histopatologi Hati Berdasarkan Degenerasi Sel

\begin{tabular}{lccc}
\hline \multirow{2}{*}{ Kelompok } & \multicolumn{2}{l}{ Rata-rata skor preparat } & Rata-rata total \\
\cline { 2 - 3 } & 1 & 2 & \\
\hline Kontrol negatif & 2,7 & 2,6 & 2,65 \\
\hline Buah merah & 1,1 & 0,6 & 0.85 \\
\hline Obat standar & 2,4 & 2,3 & 2,35 \\
\hline Rata-rata skor hepatosit normal adalah 0 &
\end{tabular}

Tabel 4 Skor Perubahan Gambaran

Histopatologi Hati Berdasarkan Nekrosis

\begin{tabular}{lccc}
\hline \multirow{2}{*}{ Kelompok } & \multicolumn{2}{c}{ Rata-vata skor preparat } & \multirow{2}{*}{ Rata-rata total } \\
\cline { 2 - 3 } & 1 & 2 & \\
\hline Kontrol negatif & 2,8 & 3 & 2,90 \\
\hline Butah merah & 1,3 & 0,6 & 0.95 \\
\hline Obat standar & 2,6 & 2,7 & 2,65
\end{tabular}

Rata-rata skor hepatosit normal adalah 0

kerusakan, baik degenerasi sel maupun nekrosis dapat diamati pada Gambar 2.

Data rata-rata skor perubahan gambaran histopatologi berdasarkan degenarasi sel digambarkan pada Tabel 3 sedangkan data rata-rata skor perubahan gambaran histopatologi berdasarkan neksosis digambarkan pada Tabel 4.
Analisa data yang berdasarkan pada persentase kerusakan hepatosit berdasarkan degenerasi sel dan nekrosis pada masingmasing kelompok ditunjukkan pada Tabel 5 dan Tabel 6

Tabel 5 Analisa Data Skor Perubahan Gambaran Histopatologi Hati Berdasarkan Degenerasi Sel

\begin{tabular}{lcc}
\hline \multicolumn{1}{c}{ Kelompok } & Rata-rata keseluruhan & \% Ketusakan \\
\hline Kontrol negatif & 2,65 & $88,3 \%$ \\
Buah merah & 0.85 & $28,3 \%$ \\
Obat standar' & 2.35 & $78,3 \%$ \\
\hline
\end{tabular}

Tabel 6 Analisa Data Skor Perubahan Gambaran Histopatologi Hati Berdasarkan Nekrosis

\begin{tabular}{lcc}
\hline \multicolumn{1}{c}{ Kelompok } & Rata-rata keselunulhan & \% Kerusakan \\
\hline Kontrol negatif & 2,90 & $96,7 \%$ \\
Buah merah & 0.95 & $31,7 \%$ \\
Obat standar & 2.65 & $88,3 \%$ \\
\hline
\end{tabular}

\section{PEMBAHASAN}

Berdasarkan hasil pemeriksaan diketahui bahwa terjadi penurunan aktivitas SGOT dan SGPT (Tabel 1) pada kelompok buah merah dan obat standar dibandingkan dengan kontrol negatif. Namun diketahui aktivitas SGPT dan SGOT kelompok obat 
standar lebih tinggi dibandingkan dengan SGPT dan SGOT kelompok buah merah. Aktivitas SGOT dan SGPT yang tinggi pada kontrol negatif disebabkan karbon tetraklorida $\left(\mathrm{CCl}_{4}\right)$ yang merupakan radikal bebas yang dapat merusak sel hati. Peningkatan aktivitas enzim SGPT dan SGOT terjadi akibat kerusakan membran sel dan membran organela yang disebabkan terputusnya ikatan karbon klorida pada $\mathrm{CCl}_{4}$ yang membentuk ion klorida dan triklormetil peroksida radikal yang merupakan radikal bebas. Bentuk radikal ini akan membentuk ikatan kovalen dengan membran mikrosomal lemak dan protein, disamping itu bentuk radikal dapat mengikat atom hidrogen dari lemak tak jenuh. Kerusakan pada hepatosit tidak hanya disebabkan kerusakan membran sel namun dapat berkembang pada kerusakan sitoplasma dan organel-organel sel. Organel sel yang dipengaruhi seperti mitokondria akan membengkak, retikulum endoplasma akan mengalami degenerasi, lisosom akan melepaskan enzim-enzim dalam darah sehingga aktivitas enzim SGPT dan SGOT meningkat. Meningkatkannya aktivitas serum tersebut sebanding dengan jumlah sel yang mengalami kerusakan (Lu, 1995).

Berdasarkan analisis anava terhadap aktivitas SGOT dan SGPT menunjukkan hasil bahwa diantara semua kelompok berbeda secara signifikan. Hasil uji LSD (Tabel 4.3 dan 4.4) didapatkan bahwa selisih rata-rata diantara 2 kelompok yang dibandingkan (antara kontrol negatif, buah merah dan obat standar) masing-masing memberikan hasil berbeda secara signifikan $(\mathrm{p}<0,05)$.

Penurunan aktivitas SGOT dan SGPT buah merah dan obat standar (hepasil) dikarenakan dimungkinkan keduanya memiliki aktivitas sebagai hepatoprotektor. Kandungan buah merah terutama betakaroten dan tokoferol memiliki fungsi sebagai antioksidan yang berperan penting dalam menangkap senyawa reaktif dan mencegah terjadinya reaksi berantai yang disebabkan oleh radikal bebas. Obat standar (hepasil) yang memiliki kandungan silybum marianum, oleum xanthorrhizae, echinacea, curcumin telah diketahui memiliki aktivitas sebagai hepatoprotektor. Sebaliknya perbandingan antara buah merah dengan obat standar diketahui bahwa buah merah memiliki aktivitas lebih baik dibandingkan dengan obat standar
Pemeriksaan histopatologi hati dilakukan untuk mengetahui sejauh mana kerusakan hepatosit akibat pemberian $\mathrm{CCl}_{4}$ dan pengaruh pemberian buah merah dan obat standar. Gambaran makroskopis kontrol negatif yang hanya diinduksi $\mathrm{CCl}_{4}$ memiliki kerusakan paling parah seperti terlihat pada Gambar 2B. Hal ini dikarenakan hati melakukan metabolisme senyawa-senyawa yang kemudian akan diubah menjadi metabolit. Apabila metabolit yang terbentuk bersifat toksik, hati akan memberikan respon berdasarkan fungsi detoksifikasi hati. Adanya zat-zat toksik dalam jumlah besar dan terus menerus dapat menyebabkan kerusakan pada sel-sel hati dikarenakan kerusakan membran sel yang dapat menyebabkan penurunan fungsi protein pompa sel, penurunan fungsi mitokondria, atau kematian sel (Koeman, 1987; Noer, 1996).

Kerusakan hepatosit karena pemberian $\mathrm{CCl}_{4}$ yang dilihat secara mikroskopis menunjukkan adanya degenerasi sel yang umumnya berupa degenerasi hidrofik dan nekrosis (kematian sel). Menurut Prince and Wilson (1984), degenerasi dikarenakan keberadaan sistem pompa sel yang menurun menyebabkan sel tidak mampu memompa ion $\mathrm{Na}$ keluar sel sehingga terjadi peningkatan konsentrasi $\mathrm{Na}$ dalam sel. Peningkatan $\mathrm{Na}$ dalam sel menyebabkan meningkatnya influks air ke dalam sel. Akibatnya terjadi pembengkakan sel atau degenerasi keruh. Pembengkakan sel secara mikroskopis terlihat sebagai sel dengan sitoplasma yang granular. Perubahanperubahan tersebut mengindikasikan bahwa sewaktu air tertimbun dalam sitoplasma maka organela sitoplasma juga menyerapnya sehingga terjadi pembengkakan mitokondria, retikulum endoplasma, dan organel lain. Jika terjadi influks air yang terus-menerus maka sebagian dari organela dalam sitoplasma berubah menjadi kantong-kantong berisi air. Meningkatnya kadar air dalam sel mengakibatkan terjadinya degenerasi hidropik. Pada pemeriksaan secara makroskopis dapat dillihat perbesaran organ atau bertambahnya berat organ melebihi normal. Degenerasi sel yang terus menerus dan berlangsung cukup lama akan menyebabkan sel tidak dapat menjalankan fungsinya sehingga terjadi kematian sel atau nekrosis sel.

Berdasarkan ketiga kelompok 
tersebut dapat diketahui bahwa kelompok buah merah memiliki persentase kerusakan yang paling kecil dibandingkan dengan kedua kelompok yang lain. Besarnya kerusakan sel akibat degenerasi ataupun nekrosis yang terjadi terbesar pada kontrol negatif yang hanya diberi $\mathrm{CCl}_{4}$ tanpa adanya hepatoprotektor sehingga persentase kerusakan sel mendekati $100 \%$ baik degenerasi sel maupun nekrosis $(88,3 \%$ dan $96,7 \%$ ). Pada kelompok yang diberikan buah merah terjadi penurunan kerusakan sel hati pada tingkat degenerasi sel dan nekrosis masing-masing sebesar $28,3 \%$ dan $31,7 \%$. Pada kelompok obat standar terjadi penurunan kerusakan sel hati pada tingkat degenerasi sel dan nekrosis masing-masing sebesar 78,3\% dan 88,3\%. Lebih rendahnya kerusakan sel pada kelompok buah merah didukung dengan semakin rendahnya aktivitas SGOT dan SGPT.

\section{KESIMPULAN}

Berdasarkan hasil penelitian buah merah dapat menurunkan aktivitas SGOT dan SGPT sehingga dapat digunakan pada pencegahan kerusakan sel yang disebabkan oleh radikal bebas. Berdasarkan hasil pemeriksaan histopatologi hepatosit mencit yang telah diberi buah merah mengalami penurunan persen kerusakan. Buah merah memiliki kemampuan yang lebih baik dibandingkan dengan obat standar (hepasil) dalam mencegah terjadinya kerusakan sel hati dengan ditunjukkan menurunnya aktivitas SGOT dan SGPT dan gambaran histopatologi hepatosit yang lebih baik.

\section{DAFTAR PUSTAKA}

Bass, N.M. 1999. Is There Any Use for Nontraditional or Alternative Therapies in Patients with Cronic Liver Desease. Curr Gastroenterol Rep 1: 50-56.

Budi, I. dan Paimin, P., R. (2005). Buah Merah. Jakarta : Penebar Swadaya

Dewi, L.K. (2002). Uji Toksisitas Sub Kronik Jamu " $X$ " secara Mikroskopis pada hati Mencit (Mus musculus) Jantan. Tidak Dipublikasikan. Skripsi. Surabaya: Fakultas Farmasi Universitas Surabaya

Halliwell, B. (1987). Oxidant and Human Deseases. Some Neew Concepts. FASEB J 4: 441-445.

Koeman, J.H. (1987). Pengantar Umum
Toksikologi. Yogyakarta : UGM Press.

Lieber, C.S. (1997). Role of Oxidative Stress and Antioxidant Therapy in Alcoholic and Nonalcoholic Liver Desease. $A d v$ Pahrmacol 38: 601-628.

Lu, F.C. (1995). Patologi Edisi I. Jakarta: Fakultas Kedoteran Universitas Indonesia.

Mishra, S.H dan Bafna, A.R. (2004). Effect Of Methanol Extract Of Achyranthes Aspera Linn. On Rifampicin Induced Hepatotoxicity In Rats. Ars Pharm; 45 (4):343-35.

Noer, S. (1996). Buku Ajar Ilmu Penyakit Dalam. Jilid I. Edsi III. Jakarta : Balai Penerbit FKUI.

Poli, G and Parola, M.(1997). Oxidative Damage and Fibrogenesis, Free Radic Biol Med 22: 287-305.

Prince, S. A., and Wilson, L. M. (1984). Patofisiologi (konsep Klinik Prosesproses Penyakit). Edisi 2. Jakarta: Penerbit Kedokteran EGC.

Romzah, V. (2005).Pengaruh Fasa Air Daun (Genarussa vulgaris Nees) tehadap Perubahan Histopatologi Hati, Ginjal dan Usus halus Mencit Jantan. Tidak Dipublikasikan. Skripsi. Surabaya : Fakultas Farmasi Universitas Airlangga

Rusmiati dan Lestari, A. 2004. Struktur Histopatologis organ Hepar dan Ren Mencit (Mus musculus L) Jantan setelah Perlakuan dengan Ekstrak kayu Secang (Caesalpinia sappan L). BIOSCIENTIAE Volume I, Nomor I; 23-30.

Sathyabudi. (2005). Buah Merah. http:// www.buahmerahonline.com [10 Desember 2005].

Sies, H. (1993). Strategies of Antioxidant Defence. Eur J Biochem 215: 213219.

Suarsana, I N., Budiasa, I K. 2005. Potensi Hepatoprotektif Ekstrak Mengkudu Pada Keracunan Parasetamol. Jurnal Veteriner (Veterinary Journal)Fakultas Kedokteran Hewan Universitas Udayana Vol 6 (3).

Thakore, K.N and Mehendale, H.M. (1991). vian Sociely for Clinical Chemistry and Clinical Physiology. 1974. Recommended Methods For The Determination Of Four Enzymes In Blood. Scand J.Clin. Lab. I 